\title{
Local User's Value Index (LUVI) of The Most Important of Medicinal Plants in Cibeo Society, Baduy-Dalam in Kanekes Village, Leuwidamar District, Lebak Regency, Banten
}

\author{
Muhamad Nikmatullah $^{1}$, Nisyawati ${ }^{1}$ and Eko Baroto Walujo $^{2}$
}

\begin{abstract}
A study of medicinal plants conservation has been undertaken in Cibeo society, by valuation Local User's Value Index (LUVI). The purpose of this study reveal the value of the most important medicinal plants based on perspective of gender dan age. Research has been conducted from September 2017 to Januari 2018. Data collection through semi-structured close-ended, open-ended, Pebble Distribution Method (PDM), Focus Group Discussion (FGD), vegetation analysis and free-roaming interviews. Based on 17 categories of diseases most commonly experienced by the Cibeo society, obtained 22 species of medicinal plants most important. According to young male and old male group, Cocos nucifera $\mathrm{L}$. is species with having the highest LUVI (2,25 and 1.95), while adult male choosed Kaempferia galanga L. (1.91). Meanwhile, based on young female group Psidium guajava $\mathrm{L}$. is species with having the highest LUVI (2.15), while adult female choosed Zingiber cassumunar Roxb (1.23), and old female choosed Cyrtandra pendula Blume (0.9). It is show that the importance of various species of medicinal plants that have been known and utilized by Cibeo society to treat disease often attack.
\end{abstract}

Keywords - Local User's Value Index (LUVI), medicinal plants, Cibeo society.

\section{INTRODUCTION}

The Cibeo Society, Baduy-Dalam still hold to maintain traditional medicine culture using medicinal plants [1]. BaduyDalam is rich biodiversity [2] and its traditional healer. Cibeo society have knowledge about utilization of medicinal plants for traditional medicine. Baduy-Dalam society has a system of knowledge transfer, called "pikukuh" [3]. Pikukuh interpreted as a delivery tradition of knowledge orally from generation to generation [4]. Emmanuel \& Didier stated that knowledge about utilization of medicinal plants is derived from the experience and heritage of medical science from close family by hereditary [5]. Knowledge about utilization of medicinal plants in the Cibeo society is inherited, so it will be easily lost, therefore it is necessary to document the knowledge of the use

Muhamad Nikmatullah ${ }^{1}$, Nisyawati ${ }^{1 *}$

${ }^{1}$ Department of Biology, Faculty of Mathematics and Natural Science, Universitas Indonesia, Depok 16424

Indonesia

Eko Baroto Walujo ${ }^{2}$

${ }^{2}$ Divison of Botany, The Indonesian Institute of Science, Cibinong, 16911

Indonesia of medicinal plants. Ethnobotany can be used as a tool for documenting indigenous knowledge in the use of plants. One of ethnobotany study conducted is a study of the conservation of medicinal plants.

Study of conservation of medicinal plants based on local knowledge of Cibeo society, has not been documented scientifically. Study of conservation of medicinal plants in the Cibeo society can be scientifically by ethnobotany studies and valuation of medicinal plants. Valuations based on the value of the most important local importance each category of disease. The purpose of this study is to express the importance of local importance of the most important medicinal plant species per category of disease based on gender perspective and age category in Cibeo, Baduy-Dalam society. Sheil said that the interests effectively didn't disclosed as price lists and quantities, but rather as a holistic assessment of relative choices [6]. Therefore knowledge can be scientifically documented before being degraded by the modernization flows.

\section{EXPERIMENTAL}

\section{A. Study Area}

The research was conducted in September to January 2018, in Cibeo, Baduy-Dalam, Kanekes, Leuwidamar, Lebak, Banten. The geographical location of the study is $6^{\circ} 27$ '27 "$6^{\circ} 30^{\prime}$ North Latitude and $108^{\circ} 3$ '9" - $106^{\circ} 44^{\prime} 55^{\text {"east }}$ longitude. The altitudes are 300-1200 meters above sea level, and the area region is $3.101,8 \mathrm{~km} 2$. The plant species Identification was conducted at Herbarium Department of Biology, Faculty of Mathematics and Natural Sciences, Universitas Indonesia (FMIPA UI) and LIPI Cibinong, Bogor.

\section{B. Materials}

The tools consisted of stationery, manuals, street boards, cameras, voice recorder, GPS, compass, 50 meter meter rollers, tap diameter, machetes, scissors, sasak, rule, spray bottles, plastic samples, plastics, thermometers, hygrometers, notebooks, identification books (Flora of Java vol. 1--3 of Backer's 1963-1967 work, Indonesian useful herbs 1-4 works by Heyne 1987, and Plant Resources of South East Asia (PROSEA), medicinal plant of Asia - Pacific), and oven. The materials were $70 \%$ alcohol, spiritus, newspaper, hanging 
label, label paper, and interview sheet. The abiotic data measurement was conducted as secondary data.

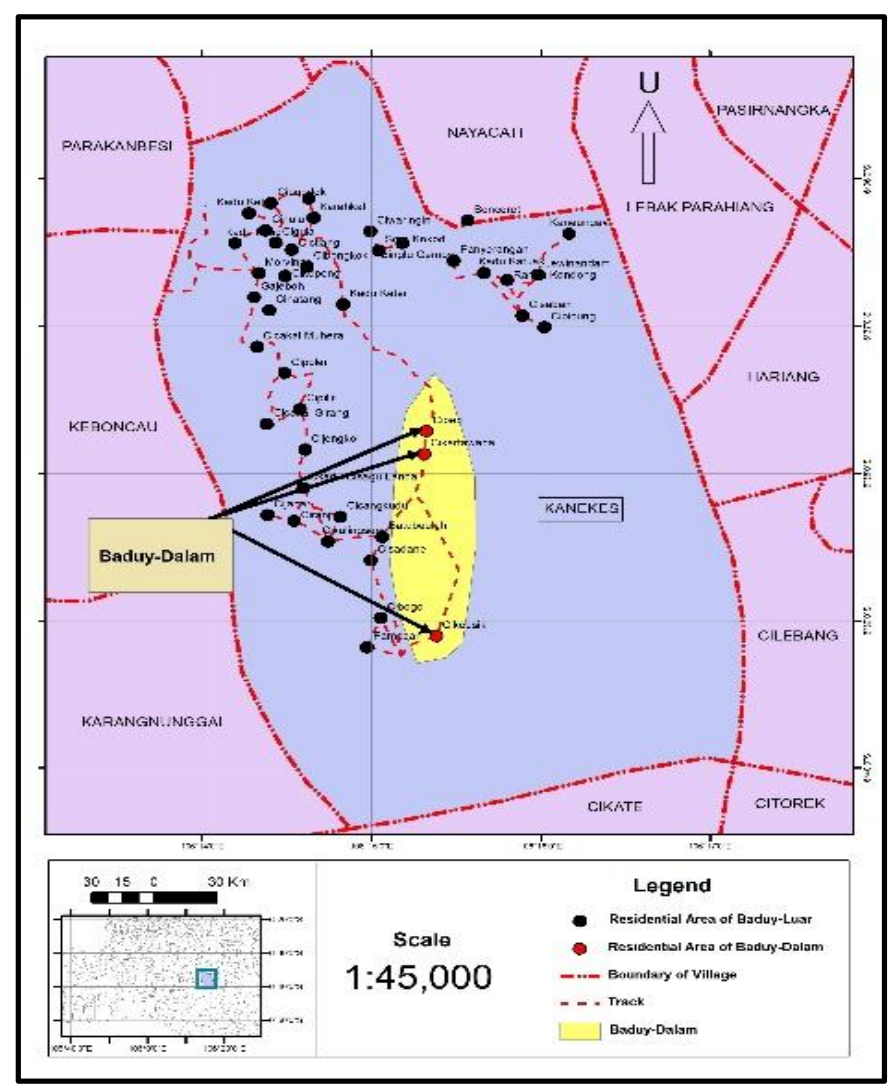

Fig. 1 Location map of Baduy-Dalam

\section{Interviews and Data Collection}

The selection of key informants was done by the purposive sampling approach. It was 3 peoples of each village (village heads, youth leaders, and shamans). The general respondents were taken as much as $10 \%$ of the total population in each village [7]. It was grouped by gender and age. By age is considered to have knowledge, divided into three categories, for men consisting of the average age of early learning and unmarried ( $\geq 6-\leq 16$ ), average age of maturing process of responsibility / married $(\leq 17-\leq 55)$, and the average age of the kakolot process or the decreasing of responsibilities and the inactivity of agriculture activities $(\leq 60)$, whereas for women the average age of early menstruation and unmarried age $(\geq 12-\leq 15)$, average age of menstrual and married productivity $(\geq 16-\leq 55)$, and average age of menopause (> 55). Interviews were conducted semi-structured, close ended and open ended with a questionnaire guide [8]. Subsequently, scoring activities were performed using the Pebble Distribution Method [6][9]. Respondents were asked to distribute 100 pebbles on card sheets that read the local name of the plant and its use according to their interests. Scoring activities were conducted in groups, each group of 6 people [6]. The determination of group members was based on informat

ion from key informants using the snow ball sampling method [8][10]. Scoring is done through focus group discussions (FGD) or focus group discussions [11]. Plant data collection was carried out with free roaming and vegetation analysis by transect using a systematic parallel lines sampling [12]. The scoring result is calculated using Local User's Value Index (LUVI).

Interviews were conducted semi-structured, close ended and open ended with a questionnaire guide [8]. Furthermore, to obtain the data of plant utilization categories based on society perception, scoring activity was done by using Pebble Distribution Method [6][9]. Respondents were asked to distribute 100 pebbles on card sheets that read the local name of the plant and its use according to their interests. Scoring activities were conducted in groups, each group of 6 people [6]. The determination of group members was based on information from key informants using the snow ball sampling method [8] [10]. Scoring is done through focus group discussions (FGD) or focus group discussions [11]. Plant data collection was carried out with free roaming and vegetation analysis by transect using a systematic parallel lines sampling [12]. The scoring result is calculated using Local User's Value Index (LUVI).

\section{RESULTS AND DISCUSSION}

\section{A. Analysis of Category Value of Disease Based on Knowledge of Cibeo Society}

The results showed that there are plants has potential as medicinal much as 87 species from 40 families in Cibeo. Based on the knowledge of Cibeo society, the medicinal plant has 41 usefulness benefits. Each category of usability has a value, obtained from the pebble distribution method (PDM).

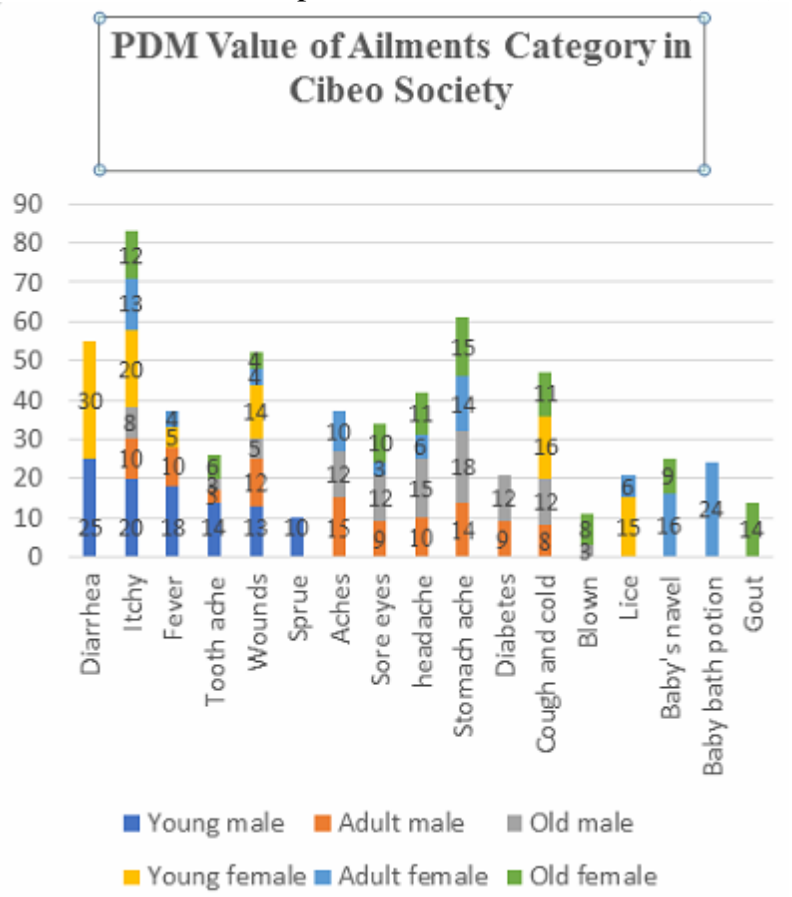

Fig. 2 PDM value of ailments category in Cibeo society 
Based on graph 1 shows that the Cibeo society has different knowledge about the types of diseases often attack. Based on age and gender categories, there is a difference knowledge of diseases between male's and female's groups. Each group of adult males, old males, adult females, and old female recognize 10 more diseases than young males and young females recognize 6 types of diseases. Differences of knowledge of the types of diseases related to knowledge about the use of medicinal plants, roles and responsibilities in the family. According to Muller the separation of gender in the division of roles and daily responsibilities influences knowledge of the use of plants [13] (Muller 2007). young male and young female, choosed diarrhea as greatest PDM values, as big as 25 and 30 . In contrast to adult and adult males, the highest PDM is aches (15) and infant bathing (24), while old male and old female the highest PDM is in abdominal pain (18 and 15). The magnitude of PDM value is related to the intensity of disease attack against Cibeo society.

\section{B. Value of Importance of Local User's Value (LUVI) of Medicinal Plants}

Based on 17 categories of diseases often attack Cibeo society, obtained 22 species of medicinal plants often utilized. Each species of medicinal plants has local user's value (LUVI) from scoring results of pebble distribution method (PDM). Each species of medicinal plant has different LUVI based on male group and female groups (graph 2). The highest LUVI in the group of young male and old male is kalapa hejo (Cocos nucifera L.) of $2.25 \%$ and $1.95 \%$, while adult male chose Cikur (Kaempferia galanga L.) of $1.91 \%$. Meanwhile, the group of young female the highest LUVI was jambu klutuk (Psidium guajava) of $2.15 \%$, while adult female chose panglai (Zingiber cassumunar Roxb.) of $1.23 \%$, and old female chose Reundeu carat (Cyrtandra pendula) of $0.9 \%$. Adults and old groups know more species of medicinal plants than young groups. Old and young groups choose Cocos nucifera as the most important species of medicinal plant with the highest LUVI. It is related with easiness of obtaining species of plant in accordance with the social activities and responsibilities. Muller said that knowledge can be attributed with social activities and age-related roles [13]. In addition, LUVI of medicinal plants influenced by the different kinds of diseases that often attack each group and confidence of society to potency plant of species. There are different species of medicinal plants which is utilized each gender. The group of adult and old male utilize Cikur (Kaempferia galanga L.) to treat aches while adult female and old female group utilize it as baby's navel medicine.

The group of young male utilized kalapa hejo (Cocos nucifera L.) as a diarrhea medicine while the group of adult male and old male as stomcah ache medicine. Water of Cocos nucifera $\mathrm{L}$ contain antimicrobial activity cause diarrhea [14]. The group of adult male also often utilizes Cikur (Kaempferia galanga L.) as aches or painful medicine, because extract of Cikur rhizome is anti-nociceptive, which can inhibit pain sensation [15].

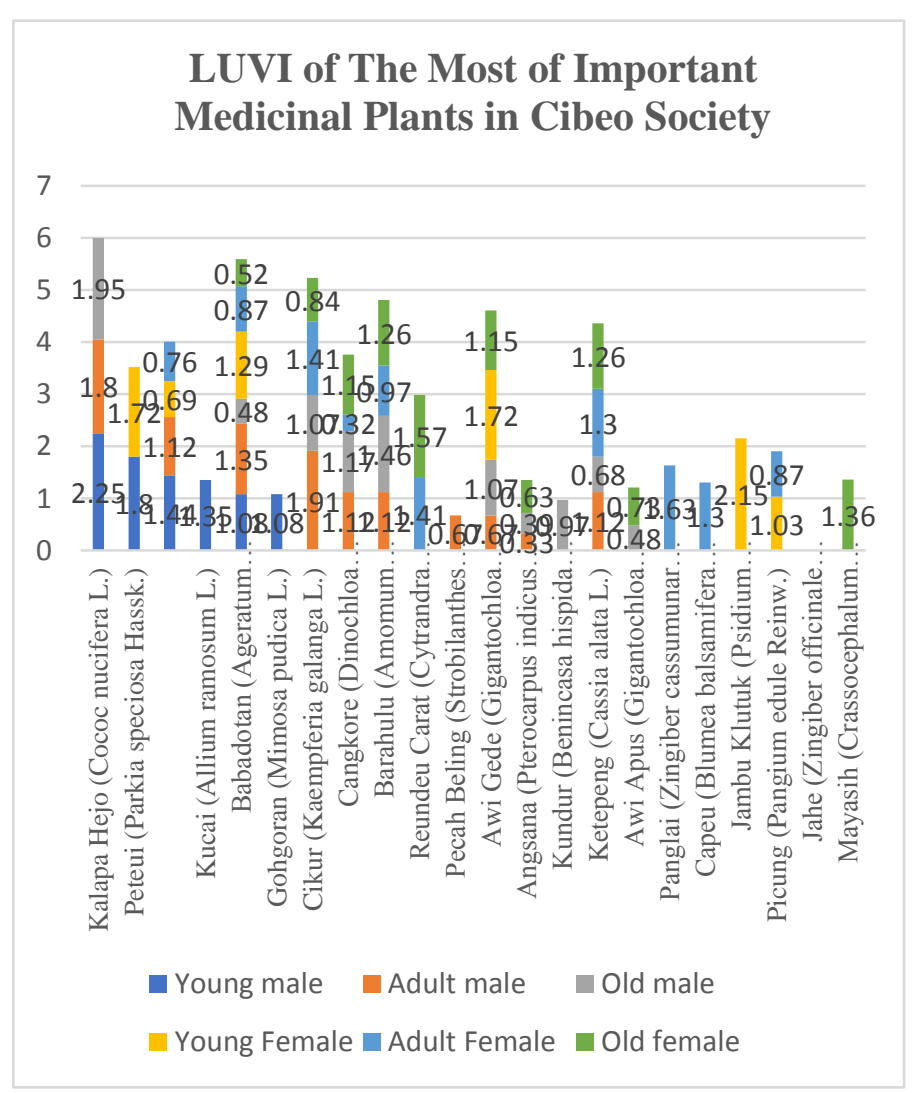

Fig. 3 LUVI of the most important medicinal plants in Cibeo society

The group of young female using jambu klutuk (Psidium guajava) as diarrhea medicine. Utilization of $P$. guajava as a diarrheal medicine also found in Baka Pygmies society in Dja, Cameroon [16] and local society in Douala, Cameroon [17], caused there are 4 antibacterial flavonoids, morin -3-Olyxoside, morin-3-O-arabinoside, quercetin, and quercetin-3O-arabinoside [18]. Meanwhile, the group of adult female utilized panglai (Zingiber cassumunar Roxb.) as a mixed of herbs for baby shower after born. Utilization of Zingiber cassumunar for baby also found in malaysia, as baby colic reliever [19]. Reundeu carat (Cyrtandra pendula) utilized as an stomach ache for adult and old female. The group of male more choose the most important of medicinal plants to treat disease while the group of female more choose the most important of medicinal plants for postpartum and hair care. It is because there are differences of interests between male's and female's group [20].

\section{CONCLUSION}

There are 22 species of medicinal plants utilized to treat 17 diseases that often attack Cibeo society. Species of medicinal plants have different the highest LUVI in each group. The highest LUVI in young male are Cocos Nucifera of $2.25 \%$, adult male Kaempferia galanga of $1.91 \%$, old male Cocos nucifera of $1.95 \%$, young female Psidium guajava of $2.15 \%$, adult female Zingiber cassumunar of $1.23 \%$, and the old female Cyrtandra pendula of $0.9 \%$. Differences LUVI influenced by the easiness of obtaining plant of species in 
accordance with social activities and responsibilities and the most important of species of medicinal plants utilized influenced by the different of types of diseases that often attack in each group and confidence of society to potency of the species of medicinal plant.

\section{ACKNOWLEDGMENT}

The authors would like to thanks Ministry Finance for funding this research through LPDP scholarship, Ministry of Finance with letter of sponsorship No: S-259/LPDP.3/2016

\section{REFERENCES}

[1] Permana, R.C.E, "Masyarakat Baduy dan pengobatan tradisional berbasis tanaman," Wacana, vol. 11, no. 1, 2009, 81--94. https://doi.org/10.17510/wjhi.v11i1.145

[2] Wardah, "Pemanfaatan keanekaragaman sumber daya tumbuhan oleh masyarakat Baduy-Dalam di sekitar Gunung Kendeng Selatan, Kabupaten Lebak, Banten Bagian Selatan," LIPI Biologi Bogor, Berita Biologi, vol. 6, no. 6, 2003, 755--765.

[3] Dewi, S.F, "Oral tradition in the study of ulayat land disputes in West Sumatera," Wacana, vol. 12, no. 1, 2010, 70--84. https://doi.org/10.17510/wjhi.v12i1.76

[4] Emmanuel, M.M. \& D.S. Didier, "Traditional knowledge on medicinal plants use by ethnic communities in Douala," Cameroon. European Journal of Medicinal Plants, vol. 2, no. 2, 2012, 159--176. https://doi.org/10.9734/EJMP/2012/878

[5] Junus, U, "Kaba and novel, a Minangkabau society: history ideas," Humaniora, vol. 12, no. 2, 2000, 181--188.

[6] Sheil, D., R.K. Puri, I. Basuki, M. van Heist, M. Wan, N. Liswanti, Rukmiyati, M.A. Sardjono, I. Samsoedin, K. Sidiyasa, Chrisandini, E. Permana, E.M. Angi, F. Gatzweiler, B. Johnson \& A. Wijaya, Mengeksplorasi keanekaragaman hayati, lingkungan dan pandangan masyarakat lokal mengenai berbagai lanskap hutan. CIFOR, Bogor: 2004, pp. 1-101.

[7] Hoft, M., S.K. Barik \& A.M. Lykke, Quantitative ethnobotany: applications of multivariate and statistical analyses in ethnobotany. United Nations Educational, Scientific and Cultural Organization, Paris, 1999, pp. 1-47

[8] Martin, G.J, Ethnobotany: a methods manual. Chapman \& Hall, London, 1995, pp. 1-268. https://doi.org/10.1007/978-1-4615-2496-0

[9] Purwanto, Y., E. Munawaroh \& R. Saparita, Prosedur dan metodologi penelitian valuasi ekonomi hasil hutan non kayu di kabupaten Malinau. LIPI Press, Jakarta, 2011, pp. 1-268

[10] Bernard, H.R, Research methods in anthropology 4th edition qualitative and quantitative approaches. Altamira Press. Rowman \& Littlefield Publisher, Inc. Lanham, 2006, pp. 1-803.

[11] Paramita, A. \& L. Kristiana, "Teknik focus group discussion dalam penelitian kualitatif." Buletin penelitian sistem kesehatan, vol. 16, no. 2 , 2013, pp. 117--127.

[12] Hidayat, S. \& R. A. Risna, "Kajian ekologi tumbuhan obat langka di Taman Nasional Bromo Tengger Semeru,"Biodiversitas, vol. 8, no. 3, pp. 169--173.

[13] Muller, J.,"Seeking women's participation in ethnoecological fieldwork," Journal of Ecological Anthropology vol. 13, 2007, pp. 64-80 https://doi.org/10.5038/2162-4593.11.1.5

[14] Nagata JM, Jew AR, Kimeu JM, Salmen CR, Bukusi EA, Cohen CR, "Medical pluralism on Mfangano Island: use of medicinal plants among persons living with HIV/AIDS in Suba District, Kenya," $J$ Ethnopharmacol, no. 135, 2011, pp. 501-509

[15] Ridtitid W, Sae-Wong C, Reanmongkol W, Wongnawa M, "Antinociceptive activity of the methanolic extract of Kaempferia galangal Linn. in experimental animals," J. Ethnopharmacol, no. 118, 2008, pp. 225-230

[16] Betti, J.L, "Medicinal plants sold in Yaoundé market, Cameroon," African

Study Monograph, vol. 23, no. 2, 2002, pp. 47--64
[17] Dibong, S.D., E.M. Mpondo, A. Ngoye \& R.J. Priso, "Modalities of exploitation of medicinal plants in Douala"s region," American Journal of Food and Nutrition, vol. 1, no. 2, 2011, pp. 67-73. https://doi.org/10.5251/abjna.2011.1.2.67.73

[18] Wang, F., Y.H. Chen, Y.J. Zhang, G.F. Deng, Z.F. Zou, A.N. Li, D.P $\mathrm{Xu}$, H.B. Li, "Chemical Components and Bioactivities of Psidium guajava," vol. 5 , no. 2,2014 , pp. 98-114

[19] Ong HC, "Rempah-ratus: Khasiatmakanan and ubatan. KaulaLumpur," Utusan Publications. 2008, pp. 82-83

[20] Begossi, A, "Women in Brazillian fisheries - considering livelihood and resilience. Dalam: International Workshop Gender, Fisheries and Aquaculture: Social capital and knowledge for the transition towards sustainable use of aquatic ecosystem," Brussel, 9 - 10 Desember 2002, pp. 1--9. 